\title{
オージェ電子分光法による表面・界面の化学状態分析
}

堤 建 一

日本電子(株) ( ₹ 196-8558 東京都昭島市武蔵野 3-1-2)

\section{Chemical State Analysis at a Solid Surface/Interface with Auger Electron Spectroscopy}

\section{Kenichi TSUTSUMI}

JEOL Ltd.(Musashino 3-1-2, Akishima, Tokyo, 196-8558)

Keywords : Auger Electron Microscopy, Chemical State Analysis, Surface, Interface, Cross-Section

\section{1.はじめに}

近年, デジタルカメラやスマートフォンを初め, 様々な電 子デバイスが高性能化・微細化され，それに含まれる電極や 多層膜の生成技術といった製造プロセス技術は日々向上して いる。そのような状況の中で表面処理の工程中で混入する不 慮の不純物や, 作業環境 (温度 - 湿度 - 䨌囲気ガス等)に依存 して生じる酸化膜や表面変質層などが, 製品の歩留まりを低 下させる大きな要因となっている。そういった工程中の不具 合を解決するためにも, 表面・界面における分析が重要であ り, 従来からオージェ電子分光法 $(\mathrm{AES})$ や X 線光電子分光 法(XPS) が広く用いられている。この 2 つの手法は, どちら も最表面から約 $6 \mathrm{~nm}$ といった浅い表面領域を分析する手法 で, 単なる表面の元素分析だけでなく, 検出された元素の結 合状態を評価する化学状態分析や，Arイオンエッチングを 併用して梁さ方向分析などを行うことができる。特に AES では集束された電子線をプローブとして用いることから微小 局所領域における元素分析を得意とし, 清浄かつダメージの 少ない断面作製が可能であるクロスセクション・ポリッ
シャー $(\mathrm{CP})^{1)}$ を利用すれば，数 $10 \mathrm{~nm}$ といった狭い金属間 化合物層の解析も可能となる。また近年では, AES を用い てXPS と同様な化学状態分析や定量分析を行う手法も提案 され ${ }^{2)}$, XPS ではケミカルシフト量が小さく解析が困難で あった遷移金属元素の化学状態であっても, AESによって 検出可能となっている。本稿では, 最新の AESの性能とそ れらを活用したアプリケーションについて簡単に紹介する。

\section{2. オージェ電子と空間分解能}

AES で検出するオージェ電子は, 図 1 に示すような 3 つ の外殼電子軌道が関与するオージェ遷移過程で生じる。オー ジェ電子の運動エネルギーは, 電子殼間のエネルギー差に よって決定されるため, 元素によって固有の運動エネルギー $\left(E_{\mathrm{AES}}\right)$ をもつことなる。

電子線を照射した際に固体表面から放出された電子のスペ クトルは，模式的には図 2 (a)のようになり，オージェ電子 のピークは二次電子のバックグラウンド上の小さなピークと して図 2 (b)のように検出される。そのピーク位置(運動エネ ルギー) は元素固有であるため, このエネルギー值を計測す

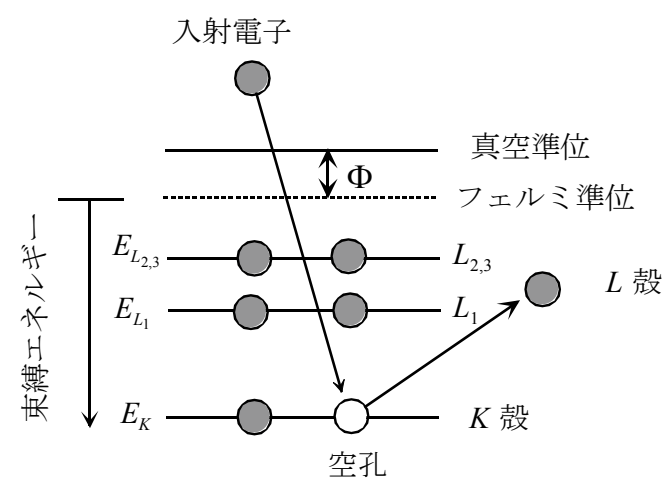

（a）励起過程

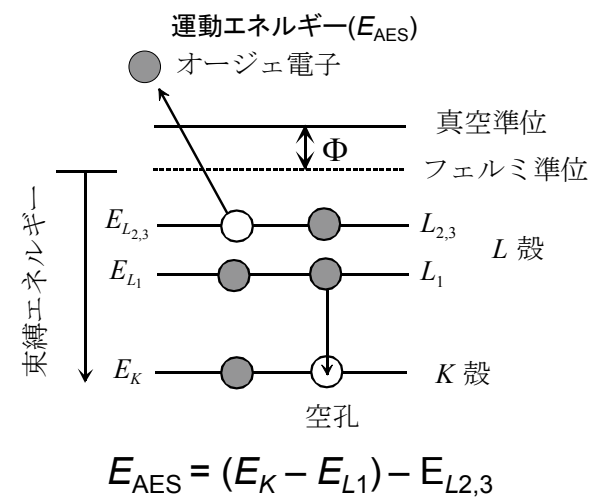

（b）オージェ電子の放出による緩和過程 (オージェ遷移過程)

図 1 オージェ電子の励起と放出過程 


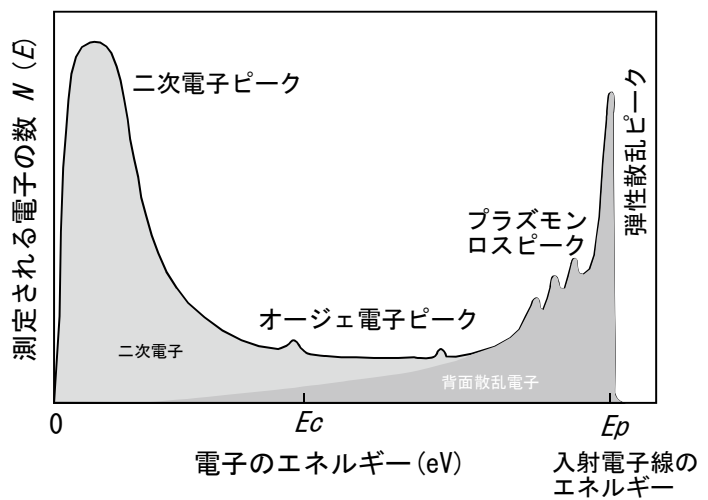

（a）電子入射時の試料表面から発生する 電子のエネルギー分布

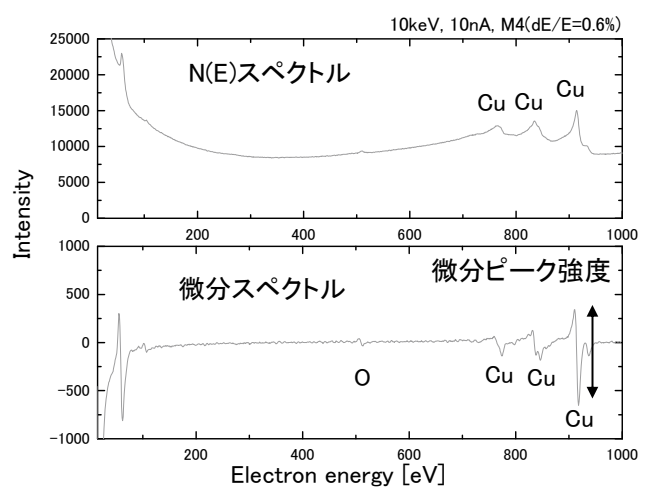

（b）実際に測定されるオージェスペクトル例

図 2 オージェスペクトルとは

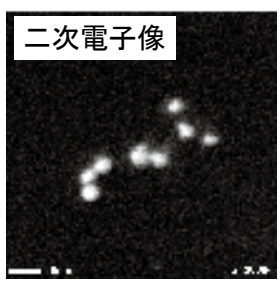

二次電子像

(測定条件: $30 \mathrm{kV}, 0.1 \mathrm{nA}$ )

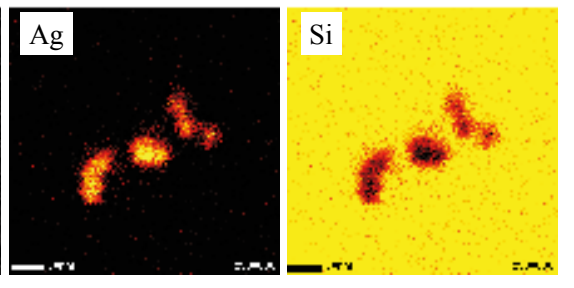

$\mathrm{Ag}$ と $\mathrm{Si}$ のオージェ面分析結果 (測定条件: $30 \mathrm{kV}, 2 \mathrm{nA}$ )
図 $3 \mathrm{Si}$ ウエハ上の $\mathrm{Ag}$ ナノ粒子の分析 (測定倍率 : 50 万倍)

ることで元素同定が可能となる。一般に, 測定に用いるオー ジェ電子の運動エネルギーは $2500 \mathrm{eV}$ 以下であり，その領域 のスペクトルを測定・解析すれば全ての元素を検出すること ができる。このように運動エネルギーが低いオージェ電子は, 試料中に含まれる原子や電子と相互作用をして弾性・非弾性 散乱を起こすため, オージェ電子の検出深さは表面からわず か数 $\mathrm{nm}$ 程度に限定される。AES が表面分析手法と呼ばれる 大きな要因である。また一方で, 検出深さよりも深い試料内 部で拡散された電子はオージェ電子の生成に全く影響しない ため, 最新の FE (Field Emission) 型 Schottky 電子銃を搭載し た AES であれば数 $10 \mathrm{kV}$ の高加速の入射電子線を用いて, 入射電子線のビーム径に近い微小領域 (約 $10 \mathrm{~nm}^{2}$ ) での分析 が可能となる。図 3 に, Si ウエハ上で直径約 $10 \mathrm{~nm}$ の $\mathrm{Ag}$ の ナノパーティクルを分散させた試料のオージェ面分析結果を 示す。この面分析の結果で $\mathrm{Ag}$ ナノパーティクルの直径が約 2 倍程度の大きさで検出できていることから, 約 $10 \mathrm{~nm}$ の空 間分解能が得られていることがわかる。

\section{3．AES に適した CP による断面作製}

最近, AES 分析が簡便に用いられる要因の一つに, 清浄 かつダメージレスな試料断面処理方法が装置として普及した ことが挙げられる。2003 年に弊社から発売されたクロスセ クション・ポリッシャー $(\mathrm{CP})^{1)}$ がそれに相当し, 最近では 加工時の熱ダメージを軽減するための液体窒素による試料冷 却機構が付いたモデルや, 加工した試料を大気に暴露するこ となく分析装置に搬送可能なモデルも登場している。図 4 に $\mathrm{CP}$ の外観写真と模式図を示す。CP とは，遮蔽板と呼ばれる

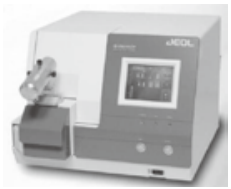

IB-09010CP

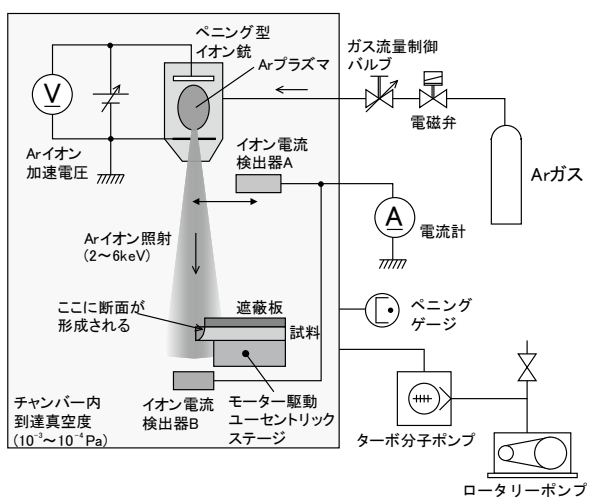

図 4

クロスセクション・ポリッシャー $(\mathrm{CP})$ の外観写真と模式図
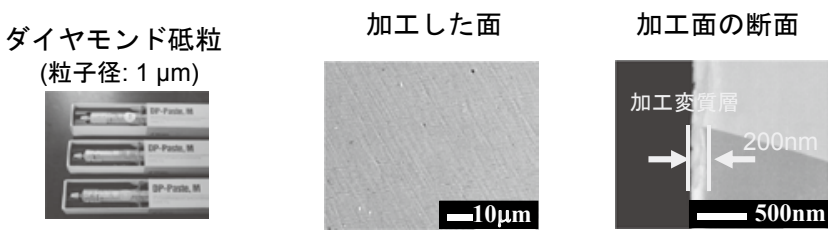

クロスセクション ポリッシャー

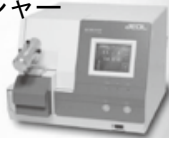

IB-09010CP
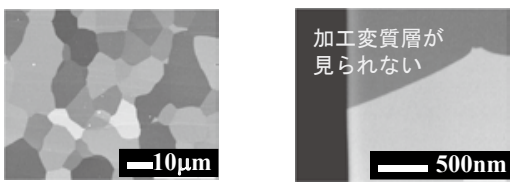

図 $5 \mathrm{Al}$ 合金試料における機械研磨面と CP 加工面の比較

ナイフエッジをもつ金属板でマスクし，遮蔽板からはみ出た 試料部を, 数 $\mathrm{kV}$ の $\mathrm{Ar}$ イオンビームを使ってマスクと共に エッチングすることで, マスク直下に清浄な断面を形成する 方法である。この方法は, 作製する断面に対して並行に $\mathrm{Ar}$ イオンビームを入射させるため, 加工変質層ができにくいと いう特長がある。一般的に用いられているダイヤモンドペー ストなどの微小砥粒(直径 $1 \mu \mathrm{m}$ 程度)を使った研磨断面では, 図 5 に示すように砥粒径よりもやや浅い表面から数 $100 \mathrm{~nm}$ の厚みの加工変質層が必ず存在する。表面から数 $\mathrm{nm}$ の領域 を分析する AES にとって, この加工変質層は大きな問題で, 
酸化するなど母材と異なる構造や定量值を示すことがある。 従来は Arエッチングで変質層を除去して AES 分析すること が常であったが, 一度でも Arイオンを使った表面エッチン グを実行すると, 選択スパッタリング現象のために AES に よる定量分析結果は, やはり母材とは異なる原子濃度を示す ことになる。このような理由でオージェ分析では正しい定量 結果が得られないといった誤解を招くことが多々あった。し かし, 現在では CP を用いることで, 図 5 のように加工変質 層の厚みは非常に薄くなり, Arエッチングしなくても AES によって母材の構造に近い定量值が得られるようになった。 その例を図 6 に示す。

ブリキ材料における $\mathrm{Sn}$ めきと $\mathrm{Fe}$ 基板との界面には $\mathrm{FeSn}_{2}$ 層と $\mathrm{FeSn}$ 層の 2 層の金属間化合物が存在する。しかし, Sn は非常に柔らかい金属であるために, 砥粒を用いた機械 研磨では界面ダレが生じやすく厚み $100 \mathrm{~nm}$ 程度の薄い $\mathrm{FeSn}_{2}$ 層が確認できないことがある。分析を行うために界面 ダレなどの加工変質層を Arエッチングで除去しようとする と, やはり選択スパッタリングの影響で $\mathrm{Sn}$ が著しく低濃度 で検出され, AES 分析では本来の $\mathrm{FeSn}_{2}$ 層と $\mathrm{FeSn}$ 層の確認 と定量分析は難しいとされていた。しかし, 図7 に示すよう に, ブリキ試料に対して CP 断面加工を行うと, CP 加工直 後の断面で定量分析した結果からも, 面分析結果からも明瞭 に $\mathrm{FeSn}_{2}$ 層と $\mathrm{FeSn}$ 層が 2 層あることが確認できた。このよ うに従来の機械研磨法では困難とされていた試料も, 加工変 質層がほとんどない清浄な断面試料が簡便に作製できるよう になったことで, 最近では前節で示した元来 AES が有して いる高い空間分解能を十分に発揮できる分析が可能になって
きた。

\section{4. オージェにおける化学状態分析}

一般的には化学状態分析といえばXPSであり，1970年代 にはAESを用いた化学状態分析の研究が数多く研究されて いたものの ${ }^{3) \sim 5)}$, 現在ではAES は微小領域での元素分析法 としてのみ用いられ，化学状態分析法としてはほとんど活用 されていない。その理由はいくつか挙げられるが, 主な要因 としては, 図 1 に示すようにオージェ遷移が複雑で, その結 果得られるオージェピークも複雑な形状を有し, ピークも複 数生じるために, ピークの帰属や解析が理論的に困難である ことが挙げられる。一方, XPS で得られる光電子ピークの 発生過程は単純で, 既知の入射 $X$ 線のエネルギーから, 発 生した光電子の運動エネルギーと仕事関数を差し引くことで, その光電子が属していた電子軌道の結合エネルギーを求める ことができる。また,バックグラウンドを除去した光電子ピー クに対して, ガウス関数とローレンツ関数の複合関数を使っ たピーク分離が可能であり，それらの分離後のピーク位置の シフト量(ケミカルシフト量)を測定することで化学状態分析 が可能となる。これがオージェピークと光電子ピークとが原 理的に異なる点であり, XPS の方が化学状態分析について 優れているとされている理由である。

しかし, 我々は多くの化学状態の標準オージェスペクトル を高エネルギー分解能で実測してみると，オージェピークの 複雑な形状は元素の化学状態によって唯一の形状を有してお り，そのピーク形状を見るだけで，およそどの元素と結合し ているのかを区別することができることに気が付いた。この

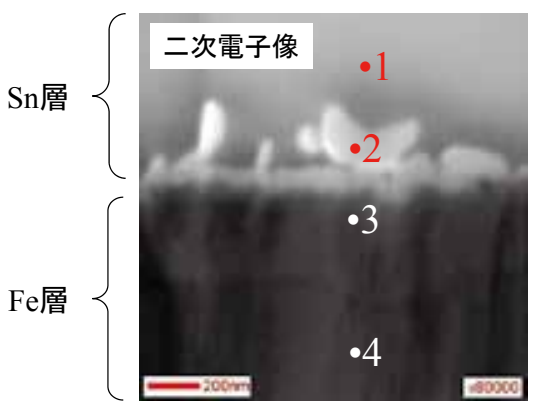

(定量結果)

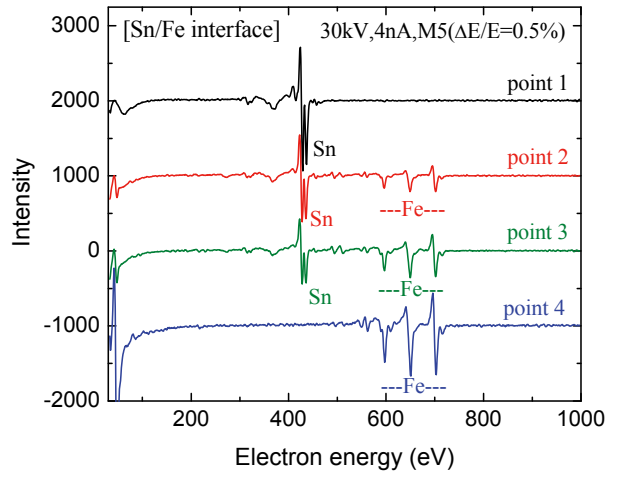

$\rightarrow \mathrm{FeSn}_{2}$

point-3. $\quad$ (Fe) $56.1 \%$, (Sn) $43.9 \% \rightarrow$ FeSn

図 $6 \mathrm{CP}$ 加工断面におけるブリキ試料の $\mathrm{Sn} / \mathrm{Fe}$ 界面での二次電子像とスペクトル分析
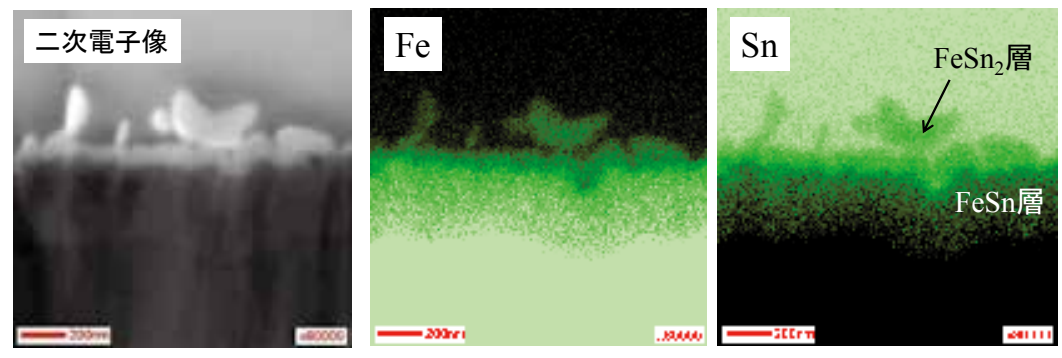

図 7 加工断面に扔けるブリキ試料の $\mathrm{Sn} / \mathrm{Fe}$ 界面でのオージェ面分析結果 
性質を利用して，実測した化合物の標準スペクトル形状を基 にし，未知試料のオージェスペクトルの形状を波形分離する ことによって化学状態分析が可能であることを報告した ${ }^{2)}$ 。 この標準スペクトル用いた波形分離方法を活用することで, XPS でも難しいとされるハンダボール表面の酸化スズの化 学状態分析を行った。

図 8 と図 9 に標準試料 $\mathrm{Sn}, \mathrm{SnO}, \mathrm{SnO}_{2}$ で高エネルギー分 解能 $0.1 \%$ で実測したSn MNN と O KLL のオージェスペク トルを示す。図 8 のスズの N (E) スペクトルを見ると、スズ は酸化 $\left(\mathrm{Sn}^{4+}\right)$ すると金属状態 $\left(\mathrm{Sn}^{0}\right)$ に比べて明らかにピーク の幅が広くなり，ピーク位置も約 $4.6 \mathrm{eV}$ 低エネルギー側へ シフトしていることがわかる。微分スペクトルを見ると， $\mathrm{Sn}^{2+}$ と $\mathrm{Sn}^{4+}$ とで酸化数に応じてピーク位置が $1.0 \mathrm{eV}$ シフト しており，その上スペクトル形状もわずかに異なっているこ とがわかる。

次に, 図 9 の $\mathrm{SnO}$ と $\mathrm{SnO}_{2}$ の酸化物で測定される酸素の久 ペクトルに注目すると，ピーク位置こそ同じであるが， $\mathrm{SnO}_{2}$ の微分形では $517 \mathrm{eV}$ 付近に彫らみができるなど全体的にス ペクトルの形状が異なっていることがわかる。このピーク形 状が異なる理由は, $\mathrm{SnO}$ と $\mathrm{SnO}_{2}$ の酸素原子から見ると基本 的にどちらも価電子が二個で同じスズ原子に共有結合してい ることから, 酸素の化学状態としてはほほ同じ状態であると 考えられる。しかし, 価電子の電子軌道のエネルギー情報を 含むオージェピークの場合には, 酸素原子内のオージェ遷移 だけでなく，この場合はスズと結合する共有結合軌道由来の
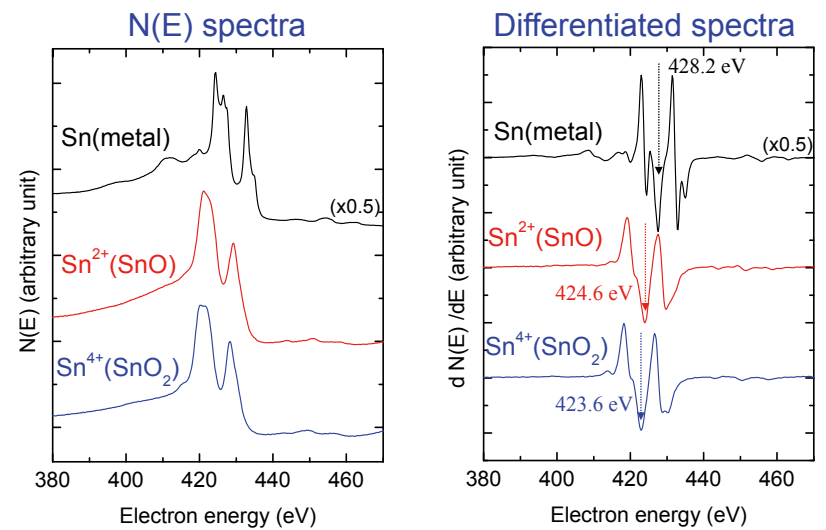

図 8

高エネルギー分解能 $(0.1 \%)$ で測定した Sn MNN オージェ スペクトル
ピークも含まれるため, 結合相手であるスズの価数の違いも 酸素ピークの形状の違いとして現れてくる。言い換えれば, $\mathrm{Sn}^{2+}$ に結合している酸素と, $\mathrm{Sn}^{4+}$ に結合している酸素は, こ のオージェピーク形状の差を利用して分離することが可能と なることを示している。

実際に，鉛フリーハンダボールの表面に形成したスズの酸 化膜の化学状態分析の例を図 10 に示す。これは，一般的に AES で用いられるエネルギー分解能 $0.5 \%$ ではなく, 化学状 態分析が可能となる高エネルギー分解能 $0.1 \%$ で深さ方向分 析測定を行い，その結果に対して，図8, 図 9 で示した $\mathrm{Sn}$ MNN スペクトルとO KLL スペクトルをそれぞれ標準スペク トルとして用いてピーク波形分離を行った結果である。詳し い計算過程については参考文献 ${ }^{2)}$ に示されているので, ここ では省略する。この波形分離結果を見ると, $\mathrm{SnO}_{2}$ に寄与し

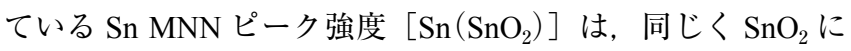
寄与しているO KLL ピーク強度 $\left[\mathrm{O}\left(\mathrm{SnO}_{2}\right)\right]$ と, 拈よそ同 ビプロファイルを示し，最表面層を形成していることがわか る。また, $\mathrm{SnO}$ に寄与している $\mathrm{Sn} \mathrm{MNN}$ ピーク強度 $[\mathrm{Sn}(\mathrm{SnO})]$ は, 同じく $\mathrm{SnO}$ に寄与している O KLL ピーク強度 $[\mathrm{O}(\mathrm{SnO})]$ と，拈よそ同じプロファイルを示し，表面から 2 番目の層を 形成していることが示されている。このようにAESにおけ る化学状態分析とは, 実測した標準スペクトルの形状との差 を利用して，測定されたオージェピークの波形分離すること である。ここで重要となるのが，波形分離に用いる標準スペ クトルの有無であるが, 最近の装置には 500 本を超える標準
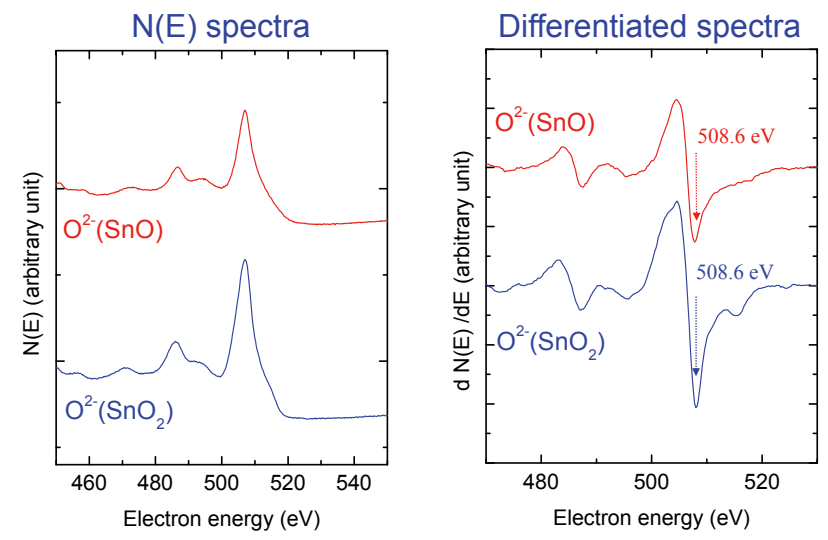

図 9 高エネルギー分解能 $(0.1 \%)$ で測定した O KLL オージェス ペクトル
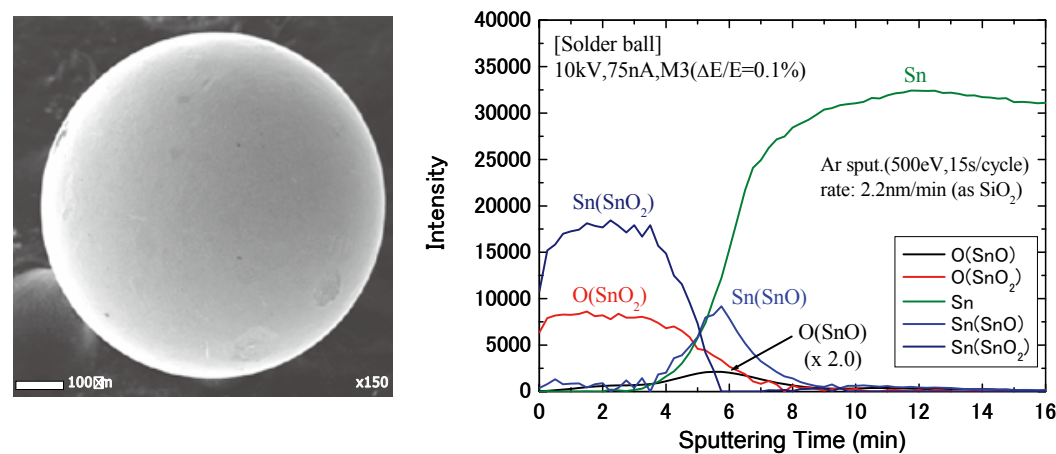

図 10 ハンダボール表面で測定した Sn と O における化学状態別の深さ方向分析結果 
スペクトルのデータベースが準備されており，ユーザーとし てはデータベースから標準スペクトルを選択して波形分離を 実施することができるソフトウエアも提供されているため, 専門的な知識がなくても AESにおける化学状態分析を簡単 に行うことができる。この方法は，今回ここで紹介した酸化 スズの化学状態分析以外にも, リチウムイオン電池材料の $\mathrm{Fe}, \mathrm{Co}, \mathrm{Ni}$ といった遷移金属の状態評価 ${ }^{6)}$ などにも応用適 用可能なので，それも併せて参照していただきたい。

\section{5.おわりに}

AES は, その原理からバルク試料を分析できる装置の中で, 最も高い空間分解能を有する方法である。そのため, AES と言えば微小領域分析のパフォーマンスばかり強調され，既 に完成された技術のような印象を持たれることがあるが，実 際にはAES のための試料前処理方法や化学状態分析の方法 など，表面分析手法としてまだ確立していかなければならな い項目が数多くある。今回は AES 用の断面作製手法として, 従来の砥粒による機械研磨面より優れた CPによる断面を紹 介し，ブリキ界面の $\mathrm{Fe}$ と $\mathrm{Sn}$ の合金層が AES で明瞭に測定 できることを示した。また，AESにおける化学状態分析は， XPS に比べてピーク形状がブロードでかつ解析が難しいこ
とから，近年ではあまり使われなくなってきているが，実測 した標準スペクトルとの形状の差を利用して, オージェピー クの波形分離することで, 化学状態分析を行う新しい方法を 紹介した。これによって, XPSでも難しいとされる酸化ス ズの化学状態分析が可能であることも示した。

AES を用いた表面・界面分析は非常に有用であり，単純 な元素分析や面分析手法に留まらず，今回示した方法により 微細な構造解析やその化学状態分析など，もっと広く活用さ れることと期待している。

(Received September 18, 2015)

\section{文献}

1 ) M. Shibata ; JEOL news, 39, 28 (2004)

2 ）堤 建一, 田中章泰, 島 政英, 田澤豊彦; 表面科学, 33,431 (2012).

3 ) J. T. Grant, T. W. Haas ; Surf. Sci., 24, 332 (1971).

4 ) G. Schon ; Surf. Sci., 35, 96 (1973).

5 ) T. Kawai, K. Kunimori, T. Kondow, T. Onishi, K. Tamaru; Phys. Rev. Lett., 33, 533 (1974).

6 ）堤 建一, 島 政英, 田中章泰; 日本電子ニュース, $46,(1), 41$ (2014) 